\title{
Jehoova tunnistajad Eestis ${ }^{1}$
}

\author{
Ringo Ringvee
}

Teesid: Artiklis käsitletakse Vahitorni Piibli ja Traktaatide Seltsi (piibliuurijad, Jehoova tunnistajad) ajalugu ja uskkonda Eestis. 1920. aastatel alustanud seltsi ametlik tegevus keelati 1935. aastal. Nõukogude võimu kehtestamise järel lahkusid välismaalastest juhid ja tegevust hakkasid koordineerima eestlased. Teine maailmasõda ei toonud kaasa suuremaid repressioone, kuid 1948. aastal algasid Jehoova tunnistajate arreteerimised, mis päädisid 1951. aasta 1. ja 2. aprillil Jehoova tunnistajate likvideerimiseks Nõukogude Liidus korraldatud operatsiooniga "Sever": Eesti Jehoova tunnistajaid küüditati koos Ukrainast, Valgevenest, Moldovast, Lätist ja Leedust pärit usklikega Tomski ümbrusse. 1960. aastate keskpaigaks õnnestus enamikul naasta kodumaale ja jätkata usuelu põrandaalusena. Massimeedia ja ateistlik propaganda naeruvääristasid neid ja kujutasid Ameerika Ühendriikide agentidena, sõjaväeteenistusest keeldujad mõisteti vangi. Vahitorni Seltsi materjale toimetati NSV Liitu salaja, paljundati ja levitati kohapeal. Eesti koguduste liikmed koordineerisid Vahitorni Seltsi tegevust Lätis, Leedus, Karjala ANSVs, Leningradis jm lähialadel. Pärast NSV Liidu lagunemist said Jehoova tunnistajad ametliku tegevusloa, neist kujunes üks kiiremini kasvav usukogukond Eestis. Kuigi jätkus vastasseis enamusühiskonnaga (nt kaitseväe kohustusest ja vereülekannetest keeldumine), oli 21. sajandi alguseks enamik probleemseid küsimusi lahendatud ja Jehoova tunnistajatest kujunenud üks viiest suuremast uskkonnast Eestis.

Märksõnad: Jehoova tunnistajad, Vahitorni Piibli ja Traktaatide Selts, usund, uususundid

Mõnikord öeldakse, et Jehoova tunnistajad on riigis valitseva tegeliku usuvabaduse lakmuspaber, kuna oma ajaloo vältel on Jehoova tunnistajaid käsitletud ohuna ühiskonnas valitsevatele normidele ja riigi institutsioonile. Autokraatlikud poliitilised režiimid on püüdnud näidata neid nii poliitiliste kui ka usuliste äärmuslastena, kelle tegevuse piiramine on ühiskonna hüvangu huvides. Selle mõtteviisi näiteid ei pea otsima kaugelt, neid leidub ka Eesti lähiajaloos. Koos vaikiva ajastu saabumisega 1934. aastal lõpetati ka Eesti Vabariigis Jehoova tunnistajate organisatsiooni tegevus ning nõukogude periood tõi kaasa Jehoova 
tunnistajate vangistamised ja küüditamise. Alljärgnev on lühikene ülevaade Jehoova tunnistajate tegevuse ajaloost Eestis.

\section{Piibliuurijatest Jehoova tunnistajateks}

19. sajand oli Ameerika Ühendriikides usuliselt vilgas aeg, mida iseloomustasid nii usulised ärkamised kui ka uued usutraditsioonid. Jehoova tunnistajate juured ulatuvad 1840. aastatel kujunenud adventliikumisse, mille keskne ootus on Kristuse peatsel taastulekul, nn teisel tulemisel ja sellega seotud piiblipõhistel uskumustel. Adventliikumise traditsiooni rajajaks peetakse baptistist ilmikjutlustajat William Millerit (1782-1849), kes kuulutas, et Kristuse saabumine leiab aset 22. oktoobril 1831. Kuigi see ennustus ei täitunud, teatas Miller piiblipõhistele arvutustele toetudes, et Kristuse teistkordne tulek leiab aset aastal 1843 ning seejärel 1844. Ka need ennustused ei täitunud ning sellele järgnes Milleri järgijate seas nn suur pettumus. Järgnevatel aastatel kujunesid välja mitmed adventliikumise suunad, millest kõige tuntum on seitsmenda päeva adventistid.

Adventliikumise arusaamadest mõjutatuna asutas Charles Taze Russell (1852-1916) oma piibliuurijate (Bible Students) ringi ning 1884 ametlikult Siioni Vahitorni Traktaadi Ühingu (Zion's Watch Tower Tract Society) piiblilise sõnumi levitamiseks. Jehoova tunnistajate ajalugu süvitisi käsitlenud George Chryssidesi sõnul olid piibliuurijad oma algusaegadel üks adventliikumise allharu, nad uskusid end kuuluvat Ilmutusraamatu 7. ja 14. peatükis mainitud 144000 pitseriga märgitu hulka, kes seisavad Kristusega tema teisel tulemisel Siioni mäel (Chryssides 2007).

Kuna maailma valitsetakse ebapiibellikest põhimõtetest lähtuvalt, on Jehoova tunnistajad pidanud oluliseks hoida endid lahus maistest võimukandjatest ja olla neutraalne poliitilistes küsimustes, sest esmatähtis on saabuv jumala kuningriik, mitte inimlikud või poliitilised struktuurid. Ehk teisisõnu: pole vaja valmistuda valimisteks ega vanduda ustavust riigile ja selle sümbolitele, valmistuma peab jumala kuningriigi saabumiseks ning selleks valmistumisel on oluliseks Matteuse evangeeliumi 24. peatüki 14 salm: "Ja seda Kuningriigi evangeeliumi kuulutatakse kogu ilmamaale, tunnistuseks kõigile rahvastele, ja siis tuleb lõpp.” Nagu varajane adventliikumine, ootasid ka Russelli piibliuurijad peatset Kristuse taastulekut ja Jehoova kuningriigi kehtestamist Maal. Russelli ettekuulutuse kohaselt pidi Kristuse teine tulemine aset leidma 1914. aastal. Kuigi Kristuse taastulek ei toimunud oodatud moel, kujunes piibliuurijate seas arusaam, et taevas toimunud lahingu tulemusel algas 1914. aastal Kristuse valitsusaeg taevas, saatan pagendati ja algas paganlike valitsuste lõpuaeg. Kindlate aastatega seotud 
lõpuaja ootused püsisid Vahitorni Seltsi traditsioonis aastani 1975. Tänapäeval püsib küll ootus Jehoova kuningriigi peatsesse teostumisse, kuid enam ei seota seda kindla kuupäeva ega aastaga.

Russelli piibliuurijatele said esimesed tõsisemad katsumused osaks Esimese maailmasõja ajal. Sõjavastasuse tõttu nähti neid riigivaenlastena ning 1918. aastal keelustati Vahitorni Ühingu tegevus Kanadas. Ühendriikides tundis nende tegevuse vastu huvi sõjaväeluure ning pärast Russeli surma piibiuurijate juhiks kerkinud Joseph Franklin Rutherfordi (1869-1942) ja teiste Vahitorni juhtisikute üle mõisteti kohut ebapatriootliku käitumise eest. Aastail 1918-1919 kandsid nad üheksa kuud vanglakaristust. Aasta hiljem vaadati nende kohtuasi uuesti üle ja kõik asjaosalised mõisteti õigeks (Redman 2000: 357).

1931. aastal said Rutherfordi juhitud piibliuurijad oma uueks nimeks Jehoova tunnistajad ning seni suhteliselt vaba struktuuriga liikumisest kujunes kiiresti hästi struktureeritud ja oma usulisi tõekspidamisi tõhusalt levitav organisatsioon. 144000 väljavalitule lisaks hakati kõnelema ka "suurest rahvahulgast", kellest on juttu Ilmutusraamatu 7. peatükis ning kes hakkavad elama taevase kuningriigi alluvuses maapealses paradiisis.

Nii Ameerika Ühendriikides kui ka Euroopas on Jehoova tunnistajad olnud usuliikumiseks, kelle hagid riigi vastu on määratlenud usuvabaduse praktiseerimise piire. Ajavahemikul 1938-1945 pöördusid Jehoova tunnistajad 24 juhtumiga Ühendriikide ülemkohtu poole usu praktiseerimise vabaduse küsimustes. Enamik nendest juhtumistest sai Jehoova tunnistajatele positiivse lahenduse.

Jehoova tunnistajate vastane tegevus oli märgatavalt radikaalsem neis riikides, kus kodanike lojaalsus riigile on olnud tähtsam kui isikuvabadused. Nii ei läinud Jehoova tunnistajad kaasa Saksamaa natsionaalsotsialistliku ideoloogiaga ning riigi-, rahvuse- ja juhitruuduse nõuetega, vaid hoiatasid tõusva militarismi eest. Jehoova tunnistajad olid esimeste seas, keda hakati aastail 1934-1935 Saksamaal saatma Dachau koonduslaagrisse. Natslikes koonduslaagrites eristati Jehoova tunnistajad alates 1937. aastast violetse kolmnurgaga ning nende kontakte teiste laagrisse saadetutega püüti hoida minimaalsena. Üle kaheksasaja Jehoova tunnistajate perede lapse paigutati Saksamaal lastekodudesse. (Wrobel 2006.) Tähelepandavaks nii natslike koonduslaagrite kui ka hilisemate Nõukogude Liidu vangilaagrite juures oli asjaolu, et Jehoova tunnistajatele pakuti võimalust vabaneda vangistustusest: nad pidid alla kirjutama oma usust lahtiütlemise dokumendile. Seda võimalust kasutasid vaid vähesed, sest nende seisukohalt tähendanuks see piibliõpetuste vääraks tunnistamist.

Jehoova tunnistajaid kiusati taga ka Nõukogude Liidus, samuti mujal maailmas, kus nendes on nähtud ohtu ühiskondlikule või religioossele stabiilsusele või status quo'le. Eelkõige on diskrimineerimise põhjuseks olnud oma usuliste veendumuste kuulutamine, nendest kinnipidamine, aga ka riigilojaalsuse 
küsimused. 20. sajandi teisel poolel on see toonud kaasa konflikte Jehoova tunnistajate ja Prantsusmaa võimude vahel. Viimastel aastatel on Venemaa võimud üha enam piiranud Jehoova tunnistajate tegevust, rakendades selleks muuhulgas ekstremismivastaseid seadusi, raskendades koosolekute korraldamist ja konfiskeerides Jehoova tunnistajate kirjandust. ${ }^{2}$

\section{Eestis}

Teadaolevalt olid esimesed Vahitorni Seltsi tegevusest huvitunud eestlased vennad Martin ja Hugo Kose, kes puutusid seltsi kirjandusega kokku Ameerika Ühendriikides. Martin Kose kohtus 1923. aastal seltsi juhi Rutherfordiga ja pärast Eestisse naasmist alustas ta tagasihoidlikku misjonitööd.

1925. aastal asutas Vahitorni Piibli ja Traktaatide Selts Kopenhaagenis oma Põhja-Euroopa harubüroo, mis hakkas koordineerima seltsi tegevust Taanis, Norras, Rootsis, Soomes, Leedus, Lätis ja Eestis. 1926 avas Vahitorni Traktaatide Selts esinduse Tallinnas Kreutzwaldi tänavas, selle tegevust asus juhtima britt Albert West. Misjonitöös osalesid nii briti kui ka soome piibliuurijad. Halbade teeolude kõrval raskendas seda asjaolu, et misjonitööd taheti teha kolmes kohalikus keeles - eesti, saksa ja vene keeles. Esimene konvent, milles osales 25 inimest, peeti Tallinnas 1928. aastal (Aastaraamat 2011: 173). 1930. aastal saabus seltsi tegevuse koordinaatoriks Eestisse šotlane Wallace Baxter, kes jäi juhiks 1940. aastani.

1922. aastal alustas Vahitorni Selts misjonitegevust raadios. Eestis edastati esimest korda Vahitorni Seltsi sõnumit eetris 1927. aastal. 1929. aastal said seltsi esindajad Eesti võimudelt eetriloa ning raadiosaadete edastamine jätkus 1934. aastani. 1932 avati Tartus iseseisev raadiojaam, mis lisaks Lõuna-Eestile oli kuuldav ka Põhja-Lätis. Oma hiilgeaegadel edastasid Eestis asuvad raadiojaamad saateid ka inglise, soome, saksa, vene ja rootsi keeles ning need olid kuuldavad lisaks Põhja-Lätile ka Soomes, Rootsis ja Nõukogude Liidu läänealadel. (Yearbook 1930: 101; Yearbook 1931: 157; Yearbook 1933: 114; Yearbook 2008: 85.) Viimased olid olulised, sest Vahitorni Seltsi üks siht 1930. aastate alguses oli misjonitöö alustamine Nõukogude Liidus. Venekeelse kuulutustööga alustasid Eestis kolm vene rahvusest Jehoova tunnistajat 1934. aastal (Yearbook 1936: 136).

Iganädalased koosolekud, kus arutleti Vahitorni Seltsi väljaannete teemadel, said tavaks 1931. aastal, mil aastas peeti 140 koosolekut ning seitse pioneeri ${ }^{3}$ koos kahe abilisega jagasid 17974 eksemplari raamatuid ja brošüüre. Vahitorni ajakirja regulaarseid tellijaid oli siiski vaid üksteist (Yearbook 1932). 


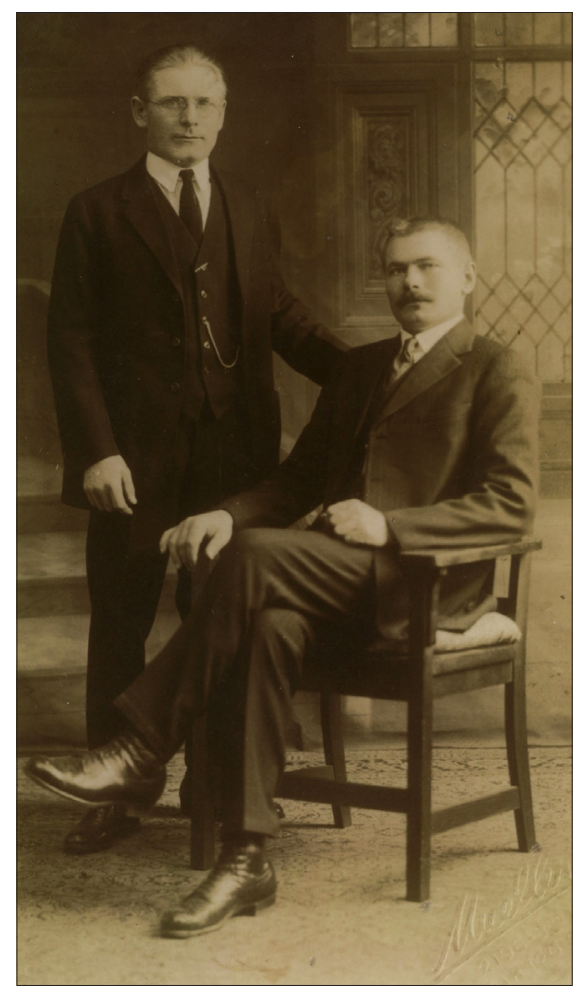

Foto 1. Esimesed eestlastest "piibliuurijad" Martin ja Hugo Kose 1920. aastatel New Yorgis. Martin Koset peetakse Vahitorni Seltsi sõnumi esimeseks toojaks Eestisse. Foto: Eesti Jehoova Tunnistajate Koguduste Liit.

15. juunil 1933 registreeriti ühingute registris Vahi-Torni Piibli ja Traktaatide Selts. Kuigi piibliuurijad soovisid algselt registreerida end Usuühingute ja nende liitude seaduse alusel usulise ühendusena, registreeriti nad siiski hariliku ühinguna Ühingute ja nende liitude seaduse alusel. Samal aastal suunati misjonitöö fookus maapiirkondadele ning seda tööd peeti edukaks (Yearbook 1934).

Riiklik suhtumine piibliuurijatesse oli valdavalt neutraalne, kuid meediakuvand neist negatiivne, nende peamine kritiseerija oli luterlik kirik. Kooskõlas üldiste Jehoova tunnistajate vastaste suundumustega maailmas hakati ka Eestis nende tegevust piirama.

12. märtsi 1934. aasta riigipöördega saabus vaikiv ajastu. Jehoova tunnistajate raadiojaama tegevusluba lõpetati juunis (Vahitorni Selts nägi selle otsuse taga rooma-katoliku kiriku tegevust). Detsembris 1934 jõustas riigivanem Konstantin Päts uue seaduse seniste usuühingute kohta. 1934. aasta Kirikute ja koguduste seadus seadis sisse uue vahekorra riigi ja kirikute ning teiste usuühingute vahel, mis tähendas muuhulgas riigi tugevamat kontrol- 


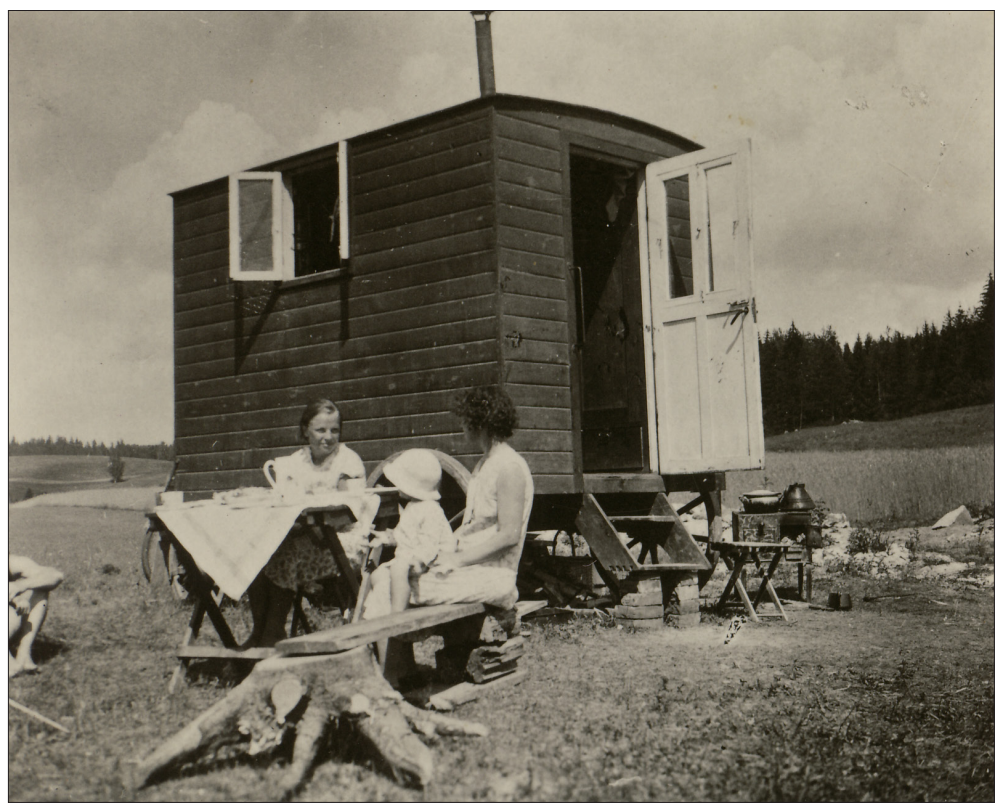

Foto 2. Vahitorni Seltsi pioneerid tegi misjonitööd maapiirkondades. Pioneer John Herbert Northi kasutas 1930. aastatel piiblisõnumi levitamiseks treilerit, mille meeskonna moodustasid J. H. North koos oma abikaasa ja lapsega ning kaks noort meespioneeri. Foto: Eesti Jehoova Tunnistajate Koguduste Liit.

li usuliste ühenduste tegevuse üle. 1935. aastal taotles Vahitorni Selts luba oma häälekandja väljaandmiseks, kuid seda keelduti andmast, algas hoopis Jehoova tunnistajate kirjanduse konfiskeerimine. Esimene konfiskeeritud trükis oli siseministri 30. jaanuari käskkirja kohaselt Õiglane valitseja. Järgmisena konfiskeeriti juulis 1935 väljaanded Kes hakkab maailma valitsema? ja Ülemaailmline sõda on lähedal. Samal ajal astuti samme Vahitorni Seltsi tegevuse lõpetamiseks Eestis. Lätis oli Jehoova tunnistajate organisatsioon suletud juba 1934. aastal.

26. juunil 1935 kuulas Saaremaa Leisi rajooni konstaabel üle Vahitorni Seltsi kolportööri. See rändkaubitseja oli Vahitorni Seltsi kirjanduse levitamisega alustanud 1934. aasta oktoobris, kuid pettus peagi. Eeldus, et selts tasub uue kaastöölise raviarved, ei teostunud: selts oli olnud valmis üksnes tõstma kasumimarginaali müüdud kirjandusest saadud summalt. Endise kolportööri sõnul olid Vahitorni Seltsi inglasest pioneer Herbert John North käskinud tal põletada riigivanema, kaitsevägede ülemjuhataja ja evangeelse luterliku kiriku piiskopi pildid. H. J. North eitas esitatud süüdistusi. Siiski sundlõpetati 18. juulil 1935. aastal Vahitorni Piibli ja Traktaatide Seltsi tegevus siseministri käskkirjaga Kaitseseisukorra seaduse alusel. Seltsi süüdistati riigile kahjuliku 


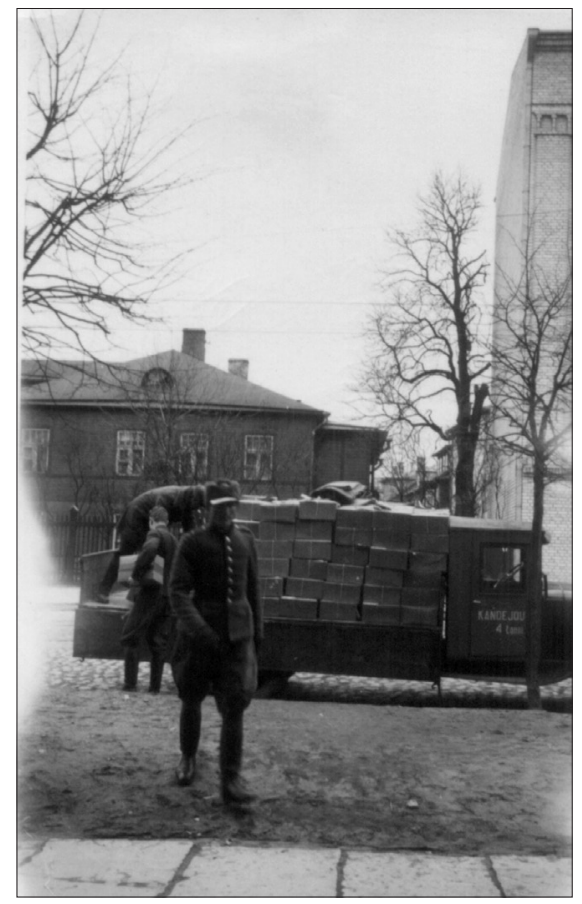

Foto 3. 20. juulil 1935. aastal konfiskeeriti Vahitorni Seltsi büroost Tallinnas 75900 trükist. Kaks päeva varem oli Vahitorni ja Piibli Traktaatide Selts sundlõpetatud kaitseseisukorra seaduse alusel. Erinevalt mitmetest teistest riikidest ei rakendatud 1930. aastate Eestis Jehoova tunnistajate vastu otseseid repressioone. Foto: Eesti Jehoova Tunnistajate Koguduste Liit.

poliitilise propaganda levitamises (sh solvangud riigipea, kirikupeade ning Rahvaste Ühenduse aadressil) ja ärevuse tekitamises kuulutustega tulevasest sõjast. Seltsi juhtkonda süüdistati juhtnööride andmises keelatud kirjanduse peitmiseks, samuti selles, et seltsi välisriigi kodanikust töötaja oli solvanud riigipead, kaitseväe ülemjuhatajat ja luterliku kiriku piiskoppi, käskides ka põletada nende fotod. Leiti, et selline tegevus oli kahjulik rahvuslikele (ja rahvusvahelistele) huvidele ja avalikule korrale ning selts on kaldunud kõrvale registreeritud põhikirjast (ERA 14.11.1342). Kaks päeva pärast seltsi sundlõpetamist konfiskeeriti 75900 eksemplari Vahitorni Seltsi kirjandust eesti, läti, soome, saksa, vene ja prantsuse keeles ning 29. juulil arestiti seltsi vara. Watch-Tower Bible and Tract Society of Pennsylvania esindaja Eestis, vandeadvokaat Jaan Poska nõudis konfiskeeritud vara ja materjalide aresti alt vabastamist, kuna see ei kuulunud siinsele Vahitorni Seltsile, vaid Ameerika Ühendriikides Pennsylvanias registreeritud seltsile. 20. augustil 1935 pöördus Ameerika Ühendriikide saatkond Eesti Vabariigi Siseministeeriumi poole Va- 
hitorni Seltsi tegevuse keelustamise ja varade arestimise küsimustes. Seltsi varad, väljaarvatud üle tosina konfiskeerimisele kuuluva väljaande, vabastati aresti alt 27. septembril. (ERA 852.1.2249.)

Järgnevatel aastatel jätkus Jehoova tunnistajate kirjanduse konfiskeerimine, kuid inimeste vastu otseseid repressioone ei rakendatud. Vahitorni Selts jätkas oma tegevust juriidilise isiku staatuseta, neid koordineeris Wallace Hendrie Baxter, kes oli olnud Vahitorni Seltsi juht ka varem. Siiski tunnistatakse 1936. aasta tegevusülevaates, et põhiliselt tehakse kuulutustööd maapiirkondades ning üldine olukord on peaaegu sama halb kui Saksamaal. 1938. aasta aprillis esitati politseile avaldus palvega uurida Vahitorni Seltsi tegevust. Poliitiline politsei tõdes 5. mail, et W. H. Baxteri ja Vahitorni Seltsi tegevus ei kujuta riigikorrale ohtu. Kaebuse esitaja oli politsei hinnangul üldiselt korralik inimene, kuid "fanaatiline adventist", kelle naine oli hakanud huvi tundma Vahitorni Seltsi kirjanduse vastu. Samal aastal rahuldati seltsi esindajate palve tagastada seltsile konfiskeeritud kirjandus. Seda lubati tingimusel, et tagastatav kirjandus viiakse Eestist välja. 6. mail 1940 alustati W. H. Baxteri suhtes juurdlust. Teda kahtlustati rooma-katoliku kiriku ja Saksamaa vastase kirjanduse levitamises. See juurdlus hääbus koos riigikorra vahetumisega Eestis. Juba 4. juulil 1940 keelustati sisekaitseülema otsusega brošüür Vaadake näkku faktidele ja õppige tundma ainsat pääseteed (ERA 852.1.2249).

Nõukogude esimese okupatsiooni alguses lahkusid Eestist välismaalastest Jehoova tunnistajad ning tegevuse korraldamine jäi esmakordselt eestlaste kanda. Kontaktid välismaal asuva keskusega katkesid aastateks. Põhja-Eestis hakkas tegevust juhtima Martin Kose, Lõuna-Eestis Friedrich Altpere. 1942. aastal hukkasid Saksa okupatsioonivõimud Tartus kuulutustööd teinud Jehoova tunnistaja Jaan Pärrati (Aastaraamat 2011: 185-188). Siiski näib, et Nõukogude võimu kehtestamine Eestis 1940. aastal ei toonud Jehoova tunnistajatele kaasa selliseid olulisi muutusi nagu teistele usulistele rühmadele ja organisatsioonidele, kellele riiklike sunnimeetodite kasutamine nende vastu oli esmakordne kogemus. Jehoova tunnistajatele tähendas nii saabunud Nõukogude võim kui ka sellele järgnenud Saksa okupatsioon üksnes tegevuse viimist senisest sügavamale "põranda alla", karistused eksimuste eest olid muutunud märgatavalt karmimaks. Samas kasvas Saksa okupatsiooni ajal seltsi liikmete hulk (Toom 1999: 10; Silliksaar 2001: 27).

Nõukogude võimu naasmine 1944. aastal kohe Jehoova tunnistajate vastaseid repressioone kaasa ei toonud. Nõukogude Liidus oli selleks hetkeks Jehoova tunnistajad usulise rühmana peaaegu likvideeritud. Katkenud kontaktid Vahitorni Seltsi keskusega tähendasid ühtlasi, et uut kirjandust Jehoova tunnistajad ei saanud, kohalikku materjali koostati juba ilmunud väljaannete 
baasil. Aastail 1947-1949 koostati ja levitati kolm numbrit väljaannet Teataja (Silliksaar 2001: 266).

1948. aastal arreteeriti viis juhtivat Jehoova tunnistajat, nende seas M. Kose ja F. Altpere ning ning nad mõisteti kümneks aastaks sunnitööle (Silliksaar 2001: 278). Jehoova tunnistajate tegevust asus korraldama neljaliikmeline teenistuskomitee. 1948. aasta augustist 1949. aasta jaanuarini oli Nõukogude Eestis arreteeritud kaheksa Jehoova tunnistajat. 22. septembril 1948 saatis teenistuskomitee selle kohta protestikirja Eesti NSV juhtkonnale, 16. detsembril samalaadse protestikirja ka Nõukogude Liidu ülemkohtule. 1949. aasta 1. juunil Tallinnas kirjutatud kirjas Nõukogude Eesti juhtkonnale, Nõukogude Liidu Ülemnõukogu presiidiumi esimehele ja Stalinile nõuti Jehoova tunnistajate represseerimise lõpetamist ja usuvabaduse tagamist.

Hoolimata repressioonidest korraldasid tunnistajad 23. juunil 1950 Otepää lähedal ühepäevase konvendi, kus osales 111 inimest erinevatest Eesti paikadest. Konvendi toimumiskohta muudeti toimumisega samal päeval, kui avastati, et nõukogude julgeolekujõud teavad toimumiskohta ning on valmis arreteerima kõik saabujad (Silliksaar 2001: 38; Aastaraamat 2011: 192). Järgneva poole aasta jooksul arreteeriti 62 Jehoova tunnistajat ja nendega seotud inimest. Arreteeritute hulgas olid ka kõik neli seni tunnistajate tegevust korraldanud komitee liiget (Silliksaar 2001: 278). Jehoova tunnistajate likvideerimiseks Nõukogude Liiduga Teise maailmasõja käigus liidetud aladelt korraldati 1951. aasta 1. ja 2. aprillil operatsioon "Sever", mille käigus küüditati 8576 Jehoova tunnistajat ja nende pereliiget või lähedast Lääne-Ukrainast, Lääne-Valgevenest, Bessaraabiast ning Leedust, Lätist ja Eestist (Polian 2003: 169-171). Eestist küüditatute koguarv oli 353 inimest, kellest oli aktiivseid tunnistajaid 81 (Silliksaar 2001: 280; RIR 6 2001: 870-879; Õispuu 2007: 17). ${ }^{4}$

Jehoova tunnistajate enesekuvandis on küüditamist nähtud ka uue võimalusena teha kuulutustööd uutel aladel. Vastupidiselt nõukogude võimude kavale, mille kohaselt oleks küüditamine lõpetanud Jehoova tunnistajatega seotud probleemid, tekitas see võimalused uue, üleliidulise Jehoova tunnistajate võrgustiku tekkeks. Nõukogude perioodil tõlgiti kirjandust peamiselt vene keele vahendusel, selle paljundamine ja levitamine sarnanes muu põrandaaluse kirjanduse paljundamise ja levitamisega. Jehoova tunnistajate tegevuses ja koosolekute korraldamisel järgiti konspiratsioonireegleid, kokkusaamiste ettekäändeiks kasutati pulmi, pulma-aastapäevi aga ka matuseid. 1951. aasta küüditamise laadseid tagakiusamisi Jehoova tunnistajatele hiljem enam osaks ei saanud, repressioonid järgnesid vaid juhtudel, kui Jehoova tunnistajad ei täitnud nõukogude ühiskonna norme - keeldusid sõjaväeteenistusest, kuulutasid piiblisõnumit jne. NSVL Ministrite Nõukogu juures asunud usukultusasjade voliniku arhiivide põhjal võib öelda, et üldülevaade Jehoova tunnistajate tege- 
vusest ja levikust oli võimuesindajatel olemas. 1965. aastaks olid deporteeritud Jehoova tunnistajad vabastatud, kuid osale neist seati liikumispiirangud ega lubatud kodukohta tagasi pöörduda. Erinevalt Lätist ja Leedust oli Eestis vaid üks selline juhtum, mis osutab, nagu oleks erinevates nõukogude liiduvabariikides rakendatud Jehoova tunnistajate suhtes erinevaid meetmeid.

1960. aastatel, kui lääneriikide turistid hakkasid Nõukogude Liitu külastama, taastasid Jehoova tunnistajad sidemed välismaal asuva keskusega. Oluline oli siinjuures Soome harubüroo tegevus. Soomest toimetati mikrofilmidel Eesti NSVsse Vahitorni Seltsi materjale ja tegevusaruandeid. Eesti Jehoova tunnistajad vahendasid ka Läti, Leedu, Leningradi, Karjala ja Murmanski Jehoova tunnistajate materjale. Kuni Tallinna ja Helsingi vahelise laevaliini avamiseni vahetati materjale Leningradis. Sellise infovahetuse korralduses oli oluline koht Soome kodakondsusega Fanny Hietalal, kes oli saabunud kuulutustööle Eestisse 1930. aastal ega lahkunud siit ka pärast nõukogude režiimi kehtestamist. Soome kodakondsuse tõttu ei küüditatud teda ka 1951. aastal (Aastaraamat 2011: 209-210, 215, 217).

1960. aastate alguses oli nõukogude ateistliku propaganda üks sihtmärk Jehoova tunnistajad, kelle kohta kasutati ühtlasi nimekuju "jehovistid". Neid naeruvääristati avalikkuses ja survestati sotsiaalselt, korraldades mh töökollektiivides sealsetest töötajatest tunnistajatega hukkamõistvaid koosolekuid (Toom 1999: 16). Jehoova tunnistajatest sai “uskliku” karikatuurne stereotüüp, keda iseloomustas nii piiratud silmaring kui ka fanaatilisus. 1962. aastal korraldati esimene avalik kohtuistung Nõukogude Eestis armeeteenistusest keeldunud Jehoova tunnistaja üle. 1964. aastal kajastas analoogset 1963. aastal toimunud kohtuprotsessi Silver Silliksaare üle kinoringvaade "Nõukogude Eesti”. Sõjaväeline väljaõpe kõrgkoolides seadis raamid ka Jehoova tunnistajate haridusteele.

1967. aastal jagasid Jehoova tunnistajad oma tegevuse organiseerimiseks Eesti neljaks koguduseks: Tallinna, Tapa ja Tartu koguduseks ning Põlva-Räpina kaksikkoguduseks. Järgnevate aastate jooksul kujunes Põlvast Jehoova tunnistajate keskus Eestis. Selle põhjused olid ajastuomaselt kummalised ning seotud Põlva rajooni tuletõrjeülemaga, kellele allusid ka korstnapühkijad. Esimene Jehoova tunnistajast korstnapühkija Põlva rajoonis oli Albert Kruus, kelle tublidus ajendas rajooni tuletõrjeülemat Valter Preedenit võtma tööle ka Kruusi usuvendi tingimusel, et usukuulutusega liiale ei minda. Vastastikuse vastutulelikkuse tulemusena töötas 1960. aastate lõpus Põlva rajooni tuletõrjes korstnapühkijate ja pottseppadena 16 Jehoova tunnistajat ligikaudu kuuekümneliikmelisest Jehoova tunnistajate kogukonnast Eestis. Korstnapühkijate töö oli ka suhteliselt vaba graafikuga, mis võimaldas teha koguduslikku tööd mitte üksnes Eestis, vaid ka Lätis ja Leedus ning 1970. aastatel ka Kaliningradi oblastis, Leningradis ja Karjalas. Põlva Jehoova tunnistajate tegevuse laienemine 
tõi kaasa nõukogude julgeoleku repressioonid, mis ei päädinud vangistusega, küll aga töökohast vallandamisega. 1970. aastate keskpaigaks oli Põlva Jehoova tunnistajate tuumik vallandatud (Silliksaar 2006).

Nõukogude repressiivse süsteemi tingimustes leidsid Jehoova tunnistajad oma usu levitamiseks erinevaid võimalusi. Vahitorni väljaandeid trükiti masinakirjast rotaprindini. Kirjutusmasinate peitmiseks ehitasid Jehoova tunnistajad oma elamutesse peidikuid. Sünnipäevad, pulmad ja matused olid nõukogude ajal Eesti vabakiriklike ringkondade oluline mitteformaalne suhtluskeskkond. Jehoova tunnistajate puhul kasutati konventide korraldamiseks pulmi ja matuseid. Silver Silliksaar on märkinud, et alates 1966. aastast muutus pulmade ajal konventide läbiviimine üldiseks ning sageli domineeris kogu sündmuse üle usuline aspekt. Pulm-konventide juures muutusid pulmad olulisemaks alates 1971. aastast, kuid säilitasid olulisuse erinevatest NSV Liidu piirkondadest pärinevate Jehoova tunnistajate kokkusaamise kohtadena (Silliksaar 2006). Pulmi kasutati piirkondlike konventide läbiviimiseks mujalgi Nõukogude Liidus, teadaolevalt toimus suurim selline kogunemine Balti liiduvabariikides 1984. aastal Leedus, kus 450 pulmakülalisest pooled tulid väljastpoolt Leedut (Gytis Tereikise e-kiri autorile 27.08.2010). Esimesed venekeelsed Jehoova tunnistajate kogudused tekkisid Eestis 1970. aastate keskel.

1980. aastate lõpu ühiskondliku surutise pehmenedes muutus ka Jehoova tunnistajate tegevus vabamaks ning tihenesid kontaktid usukaaslastega välismaal, eelkõige Soomes. 1990. aastaks oli Eestis juba 618 Jehoova tunnistajat. Pärast 56aastast tegevuskeeldu asutati esimene Jehoova tunnistajate kogudus 1991. aastal Tallinnas, järgnesid kogudused Tartus (1992) ja Maardus (1993). Need kolm kogudust asutasid 1994. aastal Eesti Jehoova Tunnistajate Koguduste Liidu (EJTKL). Aastaid kuulus EJTKLi 11 juriidilisest isikust kogudust. Praeguseks on registreeritud kogudusi neli ning ülejäänud 45 kogudust tegutsevad nö harukogudustena.

Liialdus oleks väita, nagu oleks taasiseseisvunud Eestis sujunud Jehoova tunnistajate tegevus probleemideta. See puudutab eriti 1990. aastaid, mil nõukogude massimeedia loodud "pimeda uskliku" võrdkuju kuvand elas visalt oma elu ning Jehoova tunnistajate aktiivset kuningriigi sõnumi kuulutamist, nn ukselt uksele misjonit või tänaval piiblilise kirjanduse jagamist-pakkumist kogesid paljud pealetükkivana.

Probleeme tekitas Jehoova tunnistajatest noormeeste kaitseväeteenistusest keeldumine. Kuigi ühegi noormehe vastu kriminaalasja ei algatatud, vabastati kaitseväeteenistusest üksikjuhtumitena, kusjuures Jehoova tunnistajad pidid kinnitama iga konkreetse noormehe kuulumist koguduse liikmete hulka. Lahendus saabus aastal 1996, mil Jehoova tunnistajate ja kaitseministeeriumi läbirääkimiste tulemusena suunati esimest korda 12 asendusteenistuse valinud 
Jehoova tunnistajast noormeest Päästeameti alluvusse Kose päästekompaniis, kus neid käsitleti tsiviilisikutena. (Vabar 1996; Uus \& Kallin 1996.)

1997. aastal avaldas ajakiri Luup uudisloo, mille kohaselt keeldusid Jehoova tunnistajate lapsed bioloogia tundides evolutsiooniteooriat õppimast (Vöörmann 1997). Sensatsioonimaiguliste uudiste kommentaariks märkis Jehoova tunnistajate pressiesindaja 3. oktoobril 1997: “Jehoova tunnistajad õpivad kooliprogrammi raames evolutsiooniteooriat, kuid kindlasti ei oleks arukas nõuda, et nad peaksid seda teooriat uskuma" (Palm 1997).

Kõige tõsisem Jehoova tunnistajaid puudutanud juhtum seostub vereülekandest keeldumisega 1997. aastal, kui Jehoova tunnistajast Viktoria Melnitšenko keeldus oma reesuskonfliktiga sündinud lapse vereülekande tegemisest, nagu oli ta varasemalt keeldunud arstide soovitatud abordist (Eidemiller 1999: 14). Oma kirjas Tallinna lastehaigla arstidele võttis ta lapse surma puhul kogu vastutuse enda peale. Vastsündinu surma järel keeldus prokuratuur arstidele kuriteosüüdistust esitamast, sest arstid ei teadnud sel hetkel, kuidas tulnuks õiguslikult käituda (Nõmper 2000: 212-213). See oli esimene ning senini ainus selline kohtuasi Eestis. Kohtuprotsessi lükati edasi Jehoova tunnistajast ema uue raseduse tõttu. Kuigi ka järgmisel Viktoria Melnitšenko rasedusel esines reesuskonflikt, toimus sünnitus Rootsis verevaba meditsiini põhimõtteid järgides ning vastsündinu jäi ellu. Kohtuotsus kuulutati välja alles märtsis 2001 ning see mõistis Jehoova tunnistajast lapsevanema kuriteo koosseisu puudumise tõttu õigeks. Kohtuotsuses öeldi ka, et "ei saa väita, et laps oleks ka vereülekande puhul ellu jäänud, s.t võis surra ka vereülekande järel ja ajal". Kohtuotsuse järgselt ütles Jehoova tunnistajate suhtekorraldaja Tanel Kaljulaid, et iial ei hülga ükski Jehoova tunnistaja oma last sellepärast, et talle on tehtud vereülekanne ning lisas: "vastupidi, see inimene vajab veelgi enam hoolitsust, kaastunnet ja tähelepanu. [...] Kuid keegi ei saa keelata meile ka sõnavabadust, õigust öelda, et ma ei taha seda või teist ravi. Iseasi on, kas arst minu soovi ka aktsepteerida saab.” (Kaljulaid 2001.)

Ka 1998. aastal said Jehoova tunnistajad negatiivse meediatähelepanu osaliseks, kui Tallinna 21. Keskkooli õpilasomavalitsus süüdistas kooliruume oma koosolekute tarvis lepingu alusel kasutanud Jehoova tunnistajaid nii kooli- kui ka riigilipu rüvetamises. Süüdistuse põhjustasid Jehoova tunnistajad, kes viisid koolisaalist oma koosoleku läbiviimise ajaks välja riigi-ja koolilipu, põhjendades seda prožektorite paigutamise vajadusega, kuid jätsid lipud pärast koosoleku lõppemist paigutamata oma senistele kohtadele saalis. Õiguslikust seisukohast ei olnud tegemist lipurüvetamisega, kuid pärast intsidenti lõpetasid kool ja Jehoova tunnistajad rendilepingu (Tallinna 21. Keskkool).

Aastal 2012 võib väita, et Jehoova tunnistajad on kujunenud Eesti mitmekesise religioonimaastiku üheks osaks ning konfrontatsioon oma usupõhimõtteid 
järgivate Jehoova tunnistajate ja enamusühiskonna vahel on peaaegu kadunud. Kaitseväeteenistuse alternatiiv leiti juba 1990. aastatel, 2002. aastal jõustunud mahukas Võlaõigusseaduse peatükk tervishoiuteenuste osutamise lepingust annab võimaluse reguleerida ka verevaba meditsiiniga seotud küsimusi. Jehoova tunnistajate 2010. teenistusaasta ülevaate kohaselt tegutses Eestis keskmiselt 4203 kuulutajat ja 455 pioneeri, ristiti 132 inimest ning kokku tegutses 53 kogudust (Aastaraamat 2011: 40-41).

\section{Kokkuvõte}

Jehoova tunnistajatele on iseloomulik piibellik eluviis. Sellega kaasneb mitmete enesestmõistetavate institutsioonide ignoreerimine, mis Jehoova tunnistajate arusaama kohaselt on ebapiibellikud. Piiblis ei nõuta jõulude, sünnipäevade, isade- või emadepäeva tähistamist ega riigile truudusvande andmist.

Jehoova tunnistajate uskumused ja eluviis ignoreerivad nii üldtunnustatud kristlikke õpetusi (näiteks kolmainsusest), ühiskondlik-kultuurilisi norme (sünnipäevade tähistamine) ja riiki kui austamisobjekti (lipu austamine, hümni laulmine). Samas ei tähenda see aktiivset võitlust ebapiibellike tavade vastu, vaid pigem sisaldab see võimalust nende tavade täitmise kohustusest - olgu siis ühiskondliku või riikliku surve tõttu - vabad olla.

Samas on Jehoova tunnistajatel olnud kanda oluline roll usu-, sõna- ja mõttevabaduse rakendamise piiride määratlemisel (vt nt Redman 2000: 259-260). Jehoova tunnistajatele on olnud iseloomulik, et oma õiguste kaitseks pöördutakse võimalusel kohtu poole, kuid seda üksnes siis kui see on otseselt vajalik Jehoova tunnistajate tegevuseks.

\section{Kommentaarid}

1 Uurimistööd on toetanud Eesti Vabariigi Haridus- ja Teadusministeerium (sihtfinantseeritav teadusteema SF0180026s11) ja Euroopa Liit Euroopa Regionaalarengu Fondi Kultuuriteooria Tippkeskuse kaudu.

2 Jehoova tunnistajate ajaloost, õpetustest ja organisatsioonist vt ka Ringvee 2012: 12-17.

3 Pioneerideks nimetatakse Jehoova tunnistajad, kes pühendavad kuulutustööle 90 tundi kuus.

4 Aigi Rahi-Tamm (2003: 48) annab küüditatud Jehoova tunnistajate arvuks 259. Jehoova tunnistajate küüditamisest 1. ja 2. aprillil 1951 vt ka Rahi-Tamm 2004: 37-38; Ojatalu 2001: 868-869. 


\section{Arhiiviallikad}

\section{Eesti Riigiarhiiv}

ERA 852.1.2249. Vahi-Torni, Piibli ja Traktaatide Seltsi sulgemise, nende väljaannete konfiskeerimise ja Wallace Baxteri karistamise asjas.

ERA.14.11.1342. Ühing "Vahitorni Piibli Traktaatide Selts”.

\section{Kirjandus}

Aastaraamat 2011. Jehoova tunnistajate aastaraamat 2011. Tallinn: Eesti Jehoova Tunnistajate Koguduste Liit.

Chryssides, George 2007. Jehovah's multinational organization - globalization, theocracy and Jehovah's Witnesses. A paper presented at the 2007 International Conference, Bordeaux, France. CESNUR Center for Studies on New Religions (http://www.cesnur. org/2007/bord_chryssides.htm - 28. november 2012).

Eidemiller, Rainer 1999. Lapse õigus elule. Sotsiaaltöö 3, lk 14-15.

Nõmper, Ants 2000. Jehoova tunnistajate lapse arstide kriminaalasjast. Juridica IV, lk 212-223.

Kaljulaid, Tanel 2001. Eile lõppes ülekohtune kannatamine. Eesti Päevaleht 15. märts (http://www.epl.ee/news/arvamus/tanel-kaljulaid-eile-loppes-ulekohtunekannatamine.d?id=50871385 - 30. november 2012).

Ojatalu, Ülo 2001. Küüditatud usutunnistuse pärast. Õispuu, Leo (koost). Kü̈̈ditamine Eestist Venemaale. Juunikü̈̈ditamine 1941 \& kü̈̈ditamised 1940-1953. Tallinn: ERRB, Rahvusarhiiv, AS Andmevara, Tallinna Tehnikaülikool, Soojustehnika Instituut, Liit Memento, lk 867-869.

Palm, Eero 1997. Jehoova tunnistajad ja haridus 3.10.1997. Käsikiri.

Polian, Pavel 2003. Against their will. The history and geography of forced migrations in the USSR. Budapest \& New York: Central European University Press.

Rahi-Tamm, Aigi 2003. Mass deportations from Estonia in 1941 and 1949. The sources and current status of research. Anu Mari Koll (toim). Baltic Countries Under Occupation: Soviet and Nazi Rule 1939-91. Acta Universitatis Stockholmiensis, Studia Baltica Stockholmiensia 23. Stockholm: Almqvist \& Wiksell, lk 47-54.

Rahi-Tamm, Aigi 2004. Teise maailmasõja järgsed massirepressioonid Eestis: allikad ja uurimisseis. Tartu: Tartu Ülikooli Kirjastus (http://dspace.utlib.ee/dspace/bitstream/ handle/10062/528/rahitamm.pdf?sequence=5 - 30. november 2012).

Redman, Renee C. 2000. Jehovah's Witnesses. Finkelman, Paul (toim). Religion and American Law. An Encyclopedia. New York \& London: Garland Publishing, lk 356-367.

Ringvee, Ringo 2012. Jehoova tunnistajad. Altnurme, Lea (toim). Uued usulised ja vaimsed ühendused Eestis. Tartu: Tartu Ülikooli Kirjastus, lk 12-17. 
RIR 62001 = Õispuu, Leo (koost). Represseeritud isikute registrid. Raamat 6. Kü̈̈ditamine Eestist Venemaale. Juuniküüditamine 1941 \& kü̈̈ditamised 1940-1953. Tallinn: ERRB, Rahvusarhiiv, AS Andmevara, Tallinna Tehnikaülikool, Memento.

Silliksaar, Silver. Sinasilmitsi Siberiga. Mälestusteraamat 1951. aasta küüditamisest. Tartu: S. Silliksaar.

Silliksaar, Silver 2006. Artikleid ja tõlkeid Jehoova tunnistajatest Nõukogude Liidus. Käsikiri.

Tallinna 21. Keskkool. Kiri Jehoova Tunnistajate Tallinna Kogudusele 23.02.1998 nr 39/15. (Koopia autori valduses.)

Tereikis, Gytis 2010. E-kiri autorile 27.08.2010.

Toom, Lembit 1999. Pool sajandit totalitaarse hirmuvalitsuse all. Ärgake! 22. veebruar, lk 10-16.

Uus, Enn \& Kallin, Marek 1996. Jehoova tunnistajad teenivad riiki. Sõnumileht 13. november.

Vabar, Sven 1996. Jehoova tunnistajad teenivad aega päästekompaniis. Eesti Päevaleht 14. november (http://www.epl.ee/news/arvamus/jehoova-tunnistajad-teenivad-aegapaastekompaniis.d?id=50732887 -30 . november 2012 ).

Vöörmann, Mai 1997. Usuvennad kooli kallal. Luup 20 (51), 29. september (http://www. postimees.ee/luup/97/20/index.htm - 30. november 2012).

Wrobel, Johannes S. 2006. Jehovah's Witnesses in National Socialist concentration camps, 1933-45. Religion, State and Society 34 (2), lk 89-125 (doi:10.1080/096374906 00624691).

Õispuu, Leo (koost) 2007. Nõukogude okupatsioonivõimu kuriteod Eestis. Kü̈̈ditatud, arreteeritud, tapetud 1940-1990. Represseeritud isikute register. Nimede koondregister R1-R6. Raamat 7. Tallinn: ERRB, Rahvusarhiiv, AS Andmevara, Tallinna Tehnikaülikool, Memento.

Yearbook 1930. 1930 Year Book of the International Bible Students Association with Daily Texts and Comments. New York: International Bible Students Association.

Yearbook 1931. 1931 Year Book of the International Bible Students Association with Daily Texts and Comments. New York: International Bible Students Association.

Yearbook 1932. 1932 Year Book of the International Bible Students Association with Daily Texts and Comments. New York: International Bible Students Association.

Yearbook 1933. 1933 Year Book of the International Bible Students Association with Daily Texts and Comments. New York: International Bible Students Association.

Yearbook 1934. 1934 Yearbook of Jehovah's Witnesses. New York: Watch Tower Bible and Tract Society/International Bible Students Association.

Yearbook 1936. 1936 Yearbook of Jehovah's Witnesses. New York: Watch Tower Bible and Tract Society/International Bible Students Association.

Yearbook 2008. 2008 Yearbook of Jehovah's Witnesses. New York: Watch Tower Bible and Tract Society. 


\title{
Summary
}

\section{Jehovah's Witnesses in Estonia}

\author{
Ringo Ringvee
}

Keywords: Jehovah's Witnesses, Watchtower Bible and Tract Society, religion, new religions

The article explores the history of the Watchtower Bible and Tract Society in Estonia. The first Bible students emerged in Estonia in the 1920s, and the Society started its work in the country in 1926 when the local office was opened. In 1935 the Watchtower Society was closed down according to the Emergency Act. The Society was accused of activities that caused social unrest and damaged the interests of Estonian foreign policy. The Jehovah's Witnesses, however, although banned as an organization, continued their work in spreading the Biblical message around the country. In 1940 Estonia was incorporated into the Soviet Union. The foreign staff of the Watchtower Society left the country and from there on the Estonian Jehovah's Witnesses organized their work on their own, and their contacts with the headquarters abroad were lost. Although from 1941 to 1944 Estonia was occupied by German military forces, little action was taken against the Jehovah's Witnesses. The Soviet authorities' repressions against them started in 1948 when the leading Jehovah's Witnesses were arrested and sent to prison camps. In 1951 during the operation Sever (North) carried out by the Soviet authorities, which targeted the Jehovah's Witnesses in the new territories of the Soviet Union, almost all Witnesses were deported from Estonia to Tomsk region in Siberia. All of the Estonian Jehovah's Witnesses were gradually released by the mid-1960s. However, the Soviet anti-religious campaign targeted the Jehovah's Witnesses, stigmatizing them in the media and at their workplaces. By the late 1960s the Witnesses in Estonia had established their contacts with their headquarters in the West and started organizing the Watchtower Society's work in the Baltic countries as well as in the western part of the Russian Soviet Federative Socialist Republic, including Leningrad (St. Petersburg). Although the direct repressions against Jehovah's Witnesses during the Soviet period in Estonia were rare compared to other Soviet republics, the authorities monitored them, and conscientious objectors were imprisoned. When the Soviet regime ended in Estonia in 1991, the Jehovah's Witnesses registered their religious organization and started their missionary activities. In the 1990s there were several conflicts between the mainstream society and the Witnesses. The conflicts included conscientious objectors, blood-free medicine, the use of rented facilities for their religious services, and sensational but unsubstantiated news by the tabloid media. However, by the 2000s the problems were solved, and in a short time the Jehovah's Witnesses had become the fourth or fifth largest denomination in Estonia. 